\title{
PRESERVATIVE TREATMENT OF FENCE POSTS EVALUATION THROUGH PHOTOCOLORIMETRY SEGMENTATION PERFORMANCE ${ }^{1}$
}

\author{
Walter Torezani Neto Boschetti2*, Diego Mariano Vieira ${ }^{3}$, Jordão Cabral Moulin ${ }^{4}$, Dercílio Junior Verly \\ Lopes $^{5}$, Juarez Benigno Paes ${ }^{6}$ and Ana Márcia Macedo Ladeira Carvalho ${ }^{7}$
}

\footnotetext{
${ }^{1}$ Received on 09.11.2015 accepted for publication on 30.05.2016.

${ }^{2}$ Universidade Federal de Viçosa, Programa de Pós-graduação em Ciência Florestal, Viçosa, MG - Brasil. E-mail: $<$ walterboschetti@gmail.com>.

${ }^{3}$ Universidade Federal de Viçosa, Graduado em Engenharia Florestal, Viçosa, MG - Brasil. E-mail: <diego.vieira@ufv.br>.

${ }^{4}$ Universidade Federal de Lavras, Programa de Pós-Graduação em Ciência e Tecnologia da Madeira, Lavras, MG - Brasil. E-mail:<jordao_cm@hotmail.com>.

${ }^{5}$ Universidade Federal do Espírito Santo, Programa de Pós-Graduação em Ciências Florestais e da Madeira, Jerônimo Monteiro, ES - Brasil. E-mail: <derciliolopes@hotmail.com>.

${ }^{6}$ Universidade Federal do Espírito Santo, Centro de Ciências Agrárias, Departamento de Ciências Florestais e da Madeira, Jerônimo Monteiro, ES - Brasil. E-mail: <jbp2@uol.com.br>.

${ }^{7}$ Universidade Federal de Viçosa, Departamento de Engenharia Florestal, Viçosa, MG - Brasil. E-mail: <ana.marcia@ufv.br>.

*Corresponding author.
}

\begin{abstract}
The research object was evaluating the quality of preserving treatment of Eucalyptus sp. fence posts by the sap substitution method and comparing the penetration through the traditional and photocolorimetry segmentation methods. The fence posts, 2,0 meters long and with a diameter between 8 and $12 \mathrm{~cm}$, were exposed to 2, 3 and $4 \%$ concentrations of CCB based-product active ingredients for 10 days. The penetrations were analyzed using two methodologies, one by the Image Pro Plus 4.5 software, using photocolorimetry segmentation method performance, and by analyzing the product retention in four positions of the treated fence posts. The treatment submitted pieces attained low penetration and, thus, the retention values were less than the required for direct contact with the ground. On the other hand, the proposed photocolorimetry segmentation methodology was efficient and could be an alternative to determine a more precise and fast penetration.
\end{abstract}

Keywords: Eucalyptus; Sap substitution; Penetration.

\section{AVALIAÇÃO DO TRATAMENTO PRESERVATIVO DE MOIRÕES POR MEIO DE DESEMPENHO DE SEGMENTAÇÃO FOTOCOLORIMÉTRICA}

\begin{abstract}
RESUMO - O objetivo da pesquisa foi avaliar a qualidade do tratamento preservativo de moirões de Eucalyptus sp. pelo método de substituição da seiva e comparar a penetração por meio dos métodos tradicionais e de segmentação fotocolorimétrica. Os moirões, com comprimento de 2,0 metros e diâmetro entre 8 e 12 $\mathrm{cm}$, foram expostos às concentrações de 2; 3 e 4\% de ingredientes ativos de produto a base de CCB, durante 10 dias. Foram analisadas as penetrações por duas metodologias, sendo uma pelo software Image Pro Plus 4.5, por meio de desempenho de segmentação fotocolorimétrica, e analisadas a retenção do produto em quatro posições nos moirões tratados. As peças submetidas aos tratamentos obtiveram baixa penetração, e por consequência, os valores de retenção foram inferiores do exigido para o contato direto com o solo. Por outro lado, a metodologia proposta por desempenho de segmentação fotocolorimétrica mostrou-se eficiente $e$, pode ser uma alternativa para determinar a penetração de forma mais precisa e ágil.
\end{abstract}

Palavras-chave: Eucalipto; Substituição de seiva; Penetração. 


\section{INTRODUCTION}

Fast growth species, like the Eucalyptus genus, are an option for fence post use. Although, according to Thornton et al. (1997), great part of this genus' wood shows a low or moderate resistance to xylophage organisms, specially termites and fungus, when in direct contact to the soil, thus the need of preserving them to increase their service lifespan.

To delay wood's decay, several processes or methods and chemical substances were developed. Nowadays, chemical hydrosolube products that fix themselves in the wood and make it more resistant to xylophage organisms are frequently used.

The preserving methods that use that use those products rank as industrials, when artificial pressure is used, and non-industrials, when there is no external effort to promote the preserving substance in the wood. Among the methods that do apply artificial pressure, the sap substitution one is highlighted for its easiness of use and operational simplicity, low cost of installation and the possibility of being used on small rural proprieties (LEPAGE, 1986; PAES et al., 2005; RAMOS et al., 2006).

The sap substitution method consists in treating freshly cut plump wood pieces, with high humidity and sapwood ratio. For that, the stripped wood is put vertically, with the base submerged in a vessel with hydrosolube preserving solution and, by the diffusion and capillarity phenomena, the present sap is substituted by the solution, which will provide protection against xylophages (HUNT; GARRATT, 1967; MODES et al., 2011).

Regarding the hydrosolube products, the chromated copper borate (CCB) is highlighted in the posts and fence posts treatment with or without pressure use, usually with a $2,0 \%$ of active ingredient concentration for each $\mathrm{m}^{3}$ (a.i. $\mathrm{m}^{-3}$ ) of wood (PAES et al., 2005; 2007; 2008; 2014; RAMOS et al., 2006; TORRES et al., 2011). It is important to mention that, in addition to woodrelated characteristics and treating method used, the solution concentration has influence on the quality and efficiency of the process, which is determined by retention and penetration parameters (PAES, 1991). Thus, the quantity of the product that is retained on the wood depends directly of the proportion of them presented on the treatment solution.

The penetration is the depth of the toxic layer that protects the wood. The method for determining it is ancient and is based on using two perpendicular measurings with a ruler or paquimeter and assessing that every preserved area corresponds to a circumference of same radius in its entire perimeter. Therefore, this method can sub or overestimate the results due to the non-uniformity of preservative penetration and for the $\log$ not being a perfect round circumference, corresponding in most of the cases to an elliptical aspect.

The retention refer to the amount of toxic product retained in a given wood volume. The Brazilian Regulation Standard-NBR 9480, of Brazilian Association of Technical Standards - ABNT (2009), establishes that fence post used in countryside should present total penetration of the product in the sapwood and a $6,5 \mathrm{~kg}$ a.i. $\mathrm{m}^{-3}$ minimal retention in the wood. Thus, it highlights the importance of testing distinct concentrations of preserving substances to obtain the quantity that fulfils the exigencies of the norm and verifying methodologies to improve the penetration analysis.

Therefore, the object of the research was evaluate the quality of preserving treatment of Eucalyptus sp. fence posts by the sap substitution method and comparing the penetration through the traditional and photocolorimetry segmentation methods.

\section{MATERIALAND METHODS}

\subsection{Collecting and preparing of fence posts}

Six Eucalyptus sp. trees were collected from the city of Viçosa/MG, positioned at $20^{\circ} 45^{\prime}$ 'S latitude, $42^{\circ} 52^{\prime}$ $\mathrm{W}$ longitude and $648 \mathrm{~m}$ of altitude, sectioned in 18 fence posts of $2,20 \mathrm{~m}$ of lenght and variable diameter between $8-12 \mathrm{~cm}$ that were transported to the Wood Proprieties Laboratory of the Universidade Federal de Viçosa (LPM/UFV) where they were stripped, beveled at $45^{\circ}$ and lately removed its layers of vascular cambium with a wire brush, to facilitate the sap evaporation and promoting the ascension of preserving solution into them. The period between the cut of the plants and disposition of the wood in the preserving solutions was less than 5 hours.

\subsection{Wood impregnation solution prepair}

The chromated copper borate (CCB) solution was prepared according to the NBR 9480 of ABNT (2009), made of hexavalent chromium $\left(\mathrm{CrO}_{3}, 63,5 \%\right)$, copper $(\mathrm{CuO}, 26,0 \%)$ and boron $(\mathrm{B}, 10,5 \%)$. The reagents used to prepare the CCB solution to constitute three stages 
of active ingredients (a.i.) were potassium dichromate (K2Cr2O7 . 2H2O à 2CrO3) at 1,$05 ; 1,57 ; 2,10 \mathrm{~kg}$, copper sulfate $(\mathrm{CuSO} 4$. 5H2O à $\mathrm{CuO})$ at 0,$81 ; 1,22 ; 1,62 \mathrm{~kg}$, and the boric acid (H3BO3 à $\mathrm{B}$ ) at 0,$6 ; 0,9 ; 1,2 \mathrm{~kg}$, to make 2,3 and $4 \%$ a.i. solutions.

For the wood impregnation were used three 80 liter drums. Each vessel was filled with a prepared CCB solution and six fence posts were disposed. The fence posts treatment by sap substitution, with different active ingredients concentration $(2,3$, and $4 \%$ a.i.) happened in a open and ventilated place and the fence posts were disposed vertically and partially submerged (60 $\mathrm{cm}$ from the base) on the preserving solution for 8 days and, later, inverted on the solution $(60 \mathrm{~cm}$ from the top) where they stood for 2 more days. The aerial portions of the fence posts were kept separated to proportionate good aeration between the pieces and to facilitate the solution absorption process.

\subsection{Drying and sampling of the treated fence posts.}

After the treatment, the fence posts were put to dry in a shadowy and ventilated place for 90 days for the salt fixation on the wood to happen. After this period, the beveled place was removed and two discs at positions $1 ; 2 ; 3$ e 4 were removed at the treated fence posts (Figure 1A).

In a disc of each position colorimetrical analysis were made to determinate the copper and boron elements penetration in the wood, and in the other two $1 \times 1$ $\mathrm{x} 2,5 \mathrm{~cm}$ (radial $\mathrm{x}$ tangential $\mathrm{x}$ longitudinal) samples

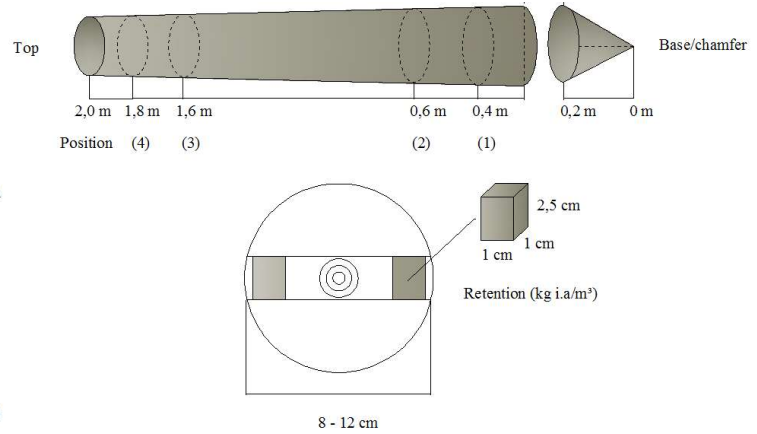

Figure 1 - Position of the disks for penetration analysis (A) and fence posts retention sample dimensions (B).

Figura 1 - Posições dos discos para a análise de penetração (A) e dimensões das amostras para a análise de retenção nos moirões (B). were cut at the sapwood region, in which $\mathrm{CCB}$ retention analysis were made (Figure 1B). The discs were identified in relation to the position in the piece and the preserving solution concentration (2, 3 and $4 \%$ a.i.).

\subsection{Colorimetrical analysis, copper and boron penetration determination}

The CCB penetration and distribution had copper and boron as base in the treated wood. Thus, the colorimetrical analysis was made according to the NBR 6232 da ABNT (2013). For such, one of the disk faces was applied with chrome azurol S, which has an intense blue color in the presence of copper, and in other one polyvynil alcohol and potassium iodide solutions to reveal a dark blue color that indicates boron.

For penetration determination, two perpendicular diameters were marked on the disks, among them, from which, with a milimetrical ruler, the depth of the revealing layers of copper and boron were measured. The average value of the measuring was used to determine the CCB constituent element penetration in each position of the fence posts. The distribution was evaluated based on the average penetration measuring across the length of each fence post.

\subsection{Treated area determination by photocolorimetrical segmentation}

To determine the preserved area in the transversal section of each position in the fence posts by photocolorimetrical segmentantion, the following steps were made:

Scanning of the chrome azurol (copper penetration) and polyvinyl alcohol + potassium iodide (boron penetration) colored disks in a known region. For this $15 \mathrm{~cm}^{2}$ were used, corresponding to $1175 \mathrm{x}$ 1175 pixels (height $\mathrm{x}$ width) and $200 \times 200 \mathrm{dpi}$ (dots per inches) resolution images.

- Opening of the imagens on the Image Pro Plus 4.5 software; calibrating them to pixels to $\mathrm{cm}^{2}$ conversion (Figure 2A):

- Total area of the disk mensuration (Figure 2B);

Colorimetrical segmentation sequence application in the images by blue color sensibility (highlighted by the preserving product reaction); and to homogenize the sampling, the three primary colors of the histogram should have for a base the first peak of red coloring (Figure 2C);

Revista Árvore, Viçosa-MG, v.40, n.4, p.731-739, 2016

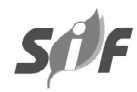


- Disposal of a mask for blue color conversion (presented in the image) in white (shining object and reference), so the other colors (that do not represent the preserving product - CCB) will appear in black (Figure 2D); and later the automatic mensuration of the shining object in the new converted image is made (Figure 2E); and
- The percentage of each disk's treated area was determined by the shining object area relation (bluecolored disk part) by the total area of the disk,

\subsection{CCB retention determination at treated wood}

To determine the $\mathrm{CCB}$ retention, the digestion of wood samples was made, obtained according to the
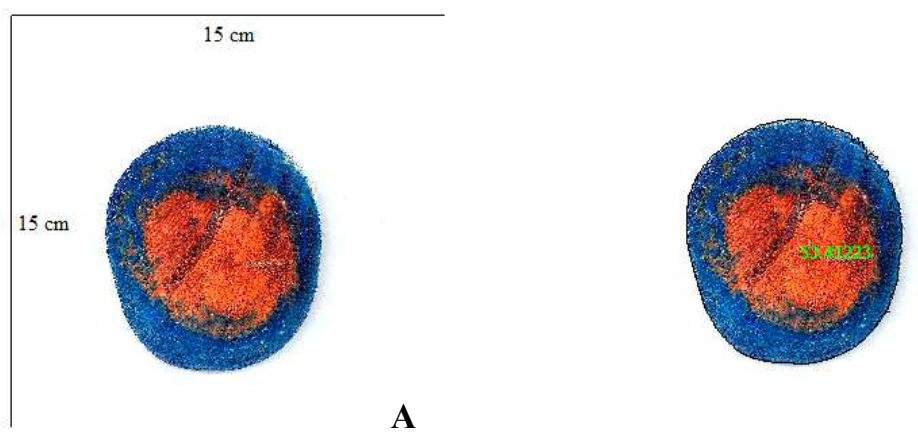

A

B

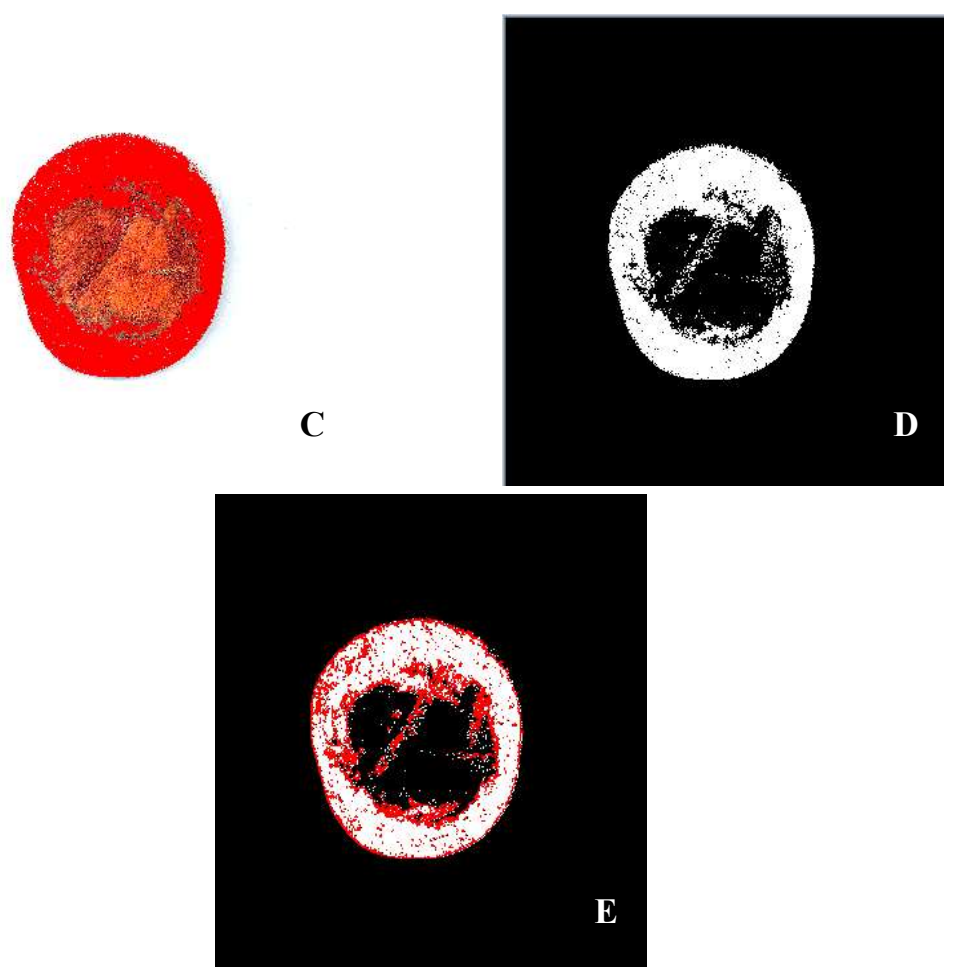

Figure 2 - Treated area mensuration of transversal section of the disk A) image calibration; B) total area mensuration of the disk; C) Segmentation performance realization with histogram based on the first blue coloration peak; D) mask application; E) Shining object automatic mensuration.

Figura 2 - Mensuração da área tratada da seção transversal do disco. A) calibração das imagens; B) mensuração da área total do disco; C) realização do desempenho de segmentação com o histograma com base no primeiro pico de coloração azul; D) aplicação da máscara; E) mensuração automática do objeto brilhante.

Revista Árvore, Viçosa-MG, v.40, n.4, p.731-739, 2016 
Figure 2B. The methodology described by Wischer was followed, quoted by Moreschi (1985), in which the following stages were included:

- Samples volume determination and incineration to obtain ashes and metallic salts at $510^{\circ} \mathrm{C}$;

- Addition of $3 \mathrm{~mL}$ of a sulfuric, perchloric and nitric acids mix, all concentrated, at a 7:2:1 proportion, to the ashes obtained by the incineration;

Accelerated digestion by the heating of the acid and ashes mix, in a heated plate, until a clear mix appears; and

- Dilution of the acid solutions with distilled water at fixed volumes.

With the obtained data by atomic absorption of spectrophotometry and the volume determination results, obtained with a paquimeter, the calculations of the retention by using the Equation 1, quoted by Paes et al. (2005, 2012, 2014) and Torres et al. (2011), is made.

$$
\mathrm{R}=\left(\mathrm{F} * \mathrm{~L} * \mathrm{~F}_{\mathrm{d}} * 10^{-3}\right) / \mathrm{V}
$$

In which:

$\mathrm{R}=$ element retention in the $\operatorname{wood}\left(\mathrm{kg} \mathrm{m}^{-3}\right)$;

$\mathrm{F}=$ stoichiometry factor used to transform the chemical elements into oxides (copper x 1,2518= CuO; chrome x 1,9230= $\mathrm{CrO}_{3}$ );

$\mathrm{L}=$ obtained reading of the spectrophotometer $\left(\mathrm{mg} \mathrm{L}^{-1}\right)$;

$\mathrm{Fd}=$ dilution factor; and

$\mathrm{V}=$ volume of the samples used in the analysis $\left(\mathrm{cm}^{3}\right)$.

\subsection{Statistical analysis of the results}

The data was analyzed in a completely randomized design with factorial arrange $(3 \times 4)$ in which were tested the concentration of the preserving solutions, with three levels $(2 ; 3$; and $4 \%$ de a.i.); the piece position with four levels $(0,4 ; 0,6 ; 1,6 ; 1,8 \mathrm{~m})$ and three repetitions. The preserving solution penetration values $(\mathrm{cm})$, of preserved area $(\%)$ and retention $\left(\mathrm{kg} \mathrm{a.i.} \mathrm{m}^{-3}\right)$ of the $\mathrm{CCB}$ were inserted in the proposed design and compared.
When significant differences were detected by the $F$ $(p \leq 0,05)$ test for the concentrated solutions in the pieces or for the interactions between the factors, the Tukey test $(p \leq 0,05)$ was used for comparing the average values.

To evaluate the possible existing correlations between the preserving product penetration obtained by the usual methodology and the one proposed in this work, evaluated by the photocolorimetric segmentation, the Pearson correlated matriz and comparison by $\mathrm{t}$ test $(\mathrm{p} \leq 0,05)$ was used.

\section{RESULTS}

\subsection{Penetration and impregnated area by copper and boron on the treated wood}

The variance analysis indicate that the copper and boron penetration were affected by the preserving solution concentration and position on the treated fence post. The average values for each element and position in the treated wood were compared (Table 1)

The results of the alternative method proposed in this work as a manner of penetration area mensuration are also presented in the Table 1. As with the penetration average values, the copper and boron preserved area average values were significantly affected by the preserving solution concentration and the treated fence post position. There were no significant interaction between the factors.

In the Figure $3 \mathrm{~A}$ the regression curve of the copper impregnated area can be observed, in which there's a positive correlation between the proposed methodology and the usual $(r=0,88)$, with the colored area being $82 \%$ explained by the curve by the copper penetration. There also was a positive correlation when the curve is adjusted for the boron $(r=0,88)$ (Figura 3B), with the colored area being $86 \%$ explained by the curve for the boron penetration..

\subsection{CCB retention in the treated wood.}

The variance analysis has presented that the retention values of the $\mathrm{CCB}$ active ingredients were influence only by the position in the treated wood piece. The comparison between the retention average values (kg i.a. $\left.\mathrm{m}^{-3}\right)$ of the CCB for each treatment are on the Table 2.

Revista Árvore, Viçosa-MG, v.40, n.4, p.731-739, 2016

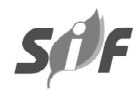


Table 1 - Average penetration and copper and boron impregnated wood area for preserving solution concentration and position in the treated wood.

Tabela 1 - Penetração média e área de madeira impregnada com cobre e boro para concentração da solução preservativa e posição na peça de madeira tratada.

\begin{tabular}{|c|c|c|c|c|c|}
\hline \multirow{2}{*}{$\begin{array}{c}\text { Concentration } \\
(\%) \\
\end{array}$} & \multicolumn{5}{|c|}{ Copper average penetration $(\mathrm{cm})$ for piece position } \\
\hline & 1 & 2 & 3 & 4 & Average \\
\hline 2 & 1,19 & 0,80 & 0,45 & 2,30 & $1,19 \mathrm{~b}$ \\
\hline 3 & 1,41 & 0,62 & 0,37 & 2,01 & $1,10 \mathrm{~b}$ \\
\hline 4 & 2,48 & 2,00 & 2,05 & 2,77 & 2,32 a \\
\hline Average & $1,69 \mathrm{AB}$ & $1,14 \mathrm{BC}$ & $0,96 \mathrm{C}$ & $2,36 \mathrm{~A}$ & \\
\hline Concentration & \multicolumn{5}{|c|}{ Boron average penetration $(\mathrm{cm})$ for piece position } \\
\hline$(\%)$ & 1 & 2 & 3 & 4 & Average \\
\hline 2 & 0,77 & 0,45 & 0,21 & 1,08 & $0,63 \mathrm{c}$ \\
\hline 3 & 1,76 & 0,57 & 0,34 & 1,30 & $0,99 \mathrm{~b}$ \\
\hline 4 & 1,38 & 0,86 & 0,47 & 3,28 & $1,50 \mathrm{a}$ \\
\hline Average & $1,30 \mathrm{~B}$ & $0,63 \mathrm{C}$ & $0,34 \mathrm{C}$ & $1,89 \mathrm{~A}$ & \\
\hline Concentration & \multicolumn{5}{|c|}{ Copper impregnated wood area (\%) for piece position } \\
\hline$(\%)$ & 1 & 2 & 3 & 4 & Average \\
\hline 2 & 44,89 & 34,27 & 37,77 & 60,08 & $44,25 \mathrm{~b}$ \\
\hline 3 & 48,89 & 37,57 & 32,70 & 52,94 & $43,01 \mathrm{~b}$ \\
\hline 4 & 79,62 & 67,82 & 65,05 & 71,27 & $70,94 \mathrm{a}$ \\
\hline Average & $57,78 \mathrm{AB}$ & $46,55 \mathrm{~B}$ & $45,18 \mathrm{~B}$ & $61,43 \mathrm{~A}$ & \\
\hline Concentration & \multicolumn{5}{|c|}{ Boron impregnated wood area (\%) for piece position } \\
\hline$(\%)$ & 1 & 2 & 3 & 4 & Average \\
\hline 2 & 34,79 & 19,27 & 25,27 & 44,34 & $30,92 \mathrm{~b}$ \\
\hline 3 & 37,23 & 27,29 & 26,39 & 47,21 & $34,53 \mathrm{~b}$ \\
\hline 4 & 51,72 & 35,10 & 56,36 & 65,98 & 52,29 a \\
\hline Average & $41,25 \mathrm{AB}$ & $27,22 \mathrm{~B}$ & $36,01 \mathrm{~B}$ & $52,51 \mathrm{~A}$ & \\
\hline
\end{tabular}

The average values followed by the same lower case letter at vertical axis or upper case on horizontal axis do not differ from each other(Tukey; $\mathrm{p}>0,05)$.
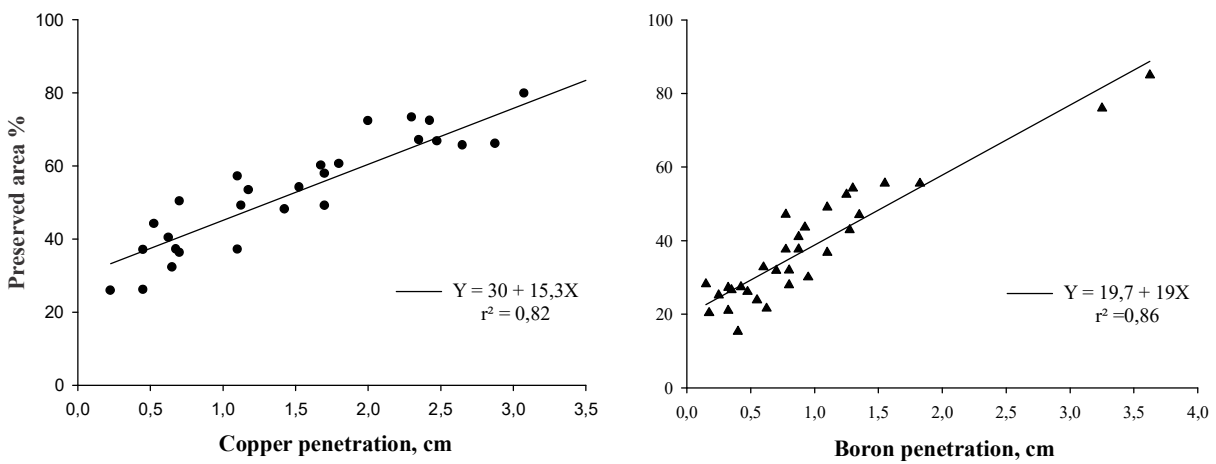

Figure 3 - Relation between impregnated area and copper (A) and boron (B) elements penetration. Figura 3 - Relação entre a área impregnada e a penetração dos elementos cobre (A) e boro (B).

\section{DISCUSSION}

\subsection{Copper and boron penetration in the treated wood}

The penetration results analysis (Table 1 ) for each position in the wood revealed that the base and top

Revista Árvore, Viçosa-MG, v.40, n.4, p.731-739, 2016 of the pieces (positions 1 and 4) presented the higher average values. The higher penetration at position 4 at $0,2 \mathrm{~m}$ from the edge of the fence post determined by the boron element came from the top inversion of the log for two days at the preserving solution and 
Table 2-CCB average retention for impregnated wood by the preserving solution concentration and position on the treated piece.

Tabela 2 - Retenção média do CCB para a madeira impregnada em função da concentração da solução preservativa e posição na peça tratada.

\begin{tabular}{|c|c|c|c|c|c|}
\hline \multirow{2}{*}{$\begin{array}{c}\text { Concentration } \\
(\%)\end{array}$} & \multicolumn{5}{|c|}{ CCB average retention ( $\mathrm{kg}$ a.i. $\mathrm{m}^{-3}$ ) for piece position } \\
\hline & 1 & 2 & 3 & 4 & Average \\
\hline 2 & 1,74 & 0,76 & 0,52 & 1,10 & 1,03 \\
\hline 3 & 6,58 & 2,25 & 1,66 & 2,12 & 3,15 \\
\hline 4 & 7,80 & 1,50 & 2,29 & 1,58 & 3,29 \\
\hline Average & $5,30 \mathrm{~A}$ & $1,50 \mathrm{~B}$ & $1,49 \mathrm{~B}$ & $1,60 \mathrm{~B}$ & \\
\hline
\end{tabular}

The average values followed by the same upper case letter on horizontal axis do not differ from each other (Tukey; $\mathrm{p}>0,05$ ).

the radial diffusion of the product to the wood interior. The samples acquired from the intermediate positions (positions 2 and 3 ) presented the lowest penetration values. This penetration behavior through the piece can be seen for both the copper and the boron in all tested concentrations.

In all of the fence posts positions, the preserving solution penetration was lower than the recommended by the NBR 9480, ABNT (2009).

Paes (1991) observed that the total penetration of the preserving product in the sapwood of hardwood, as stipulated by quoted norm, is hardly achieved by the non-industrial methods usage. Thus, Paes et al. (2005) and Farias Sobrinho et al. (2005) consider a superior that $1,0 \mathrm{~cm}$ penetration satisfactory, most of times successful in proving protection for the wood.

Analyzing the copper penetration, the fence posts treated in the $4 \%$ a.i. solution presented higher average values than the ones treated in the 2 and $3 \%$ a.i. solutions.

Yet for the boron average penetration the preserving solutions with 2, 3 and $4 \%$ a.i. presented notable differences between the average penetration values and the higher the a.i. concentration the higher the boron penetration. In addition, only the $4 \%$ concentration granted the pieces an average penetration layer higher than $1 \mathrm{~cm}$.

The copper presented penetration values higher than boron in all the analyzed positions of all tested concentrations, with the exception of the position 4 treat with the $4 \%$ solution. Such results can be explained by the copper presenting a clearer reaction than the boron (Paes et al., 2005), which can make its measurement more difficult. However, Paes (1991), Farias Sobrinho (2003) and Paes et al. (2005) observed distinct results that determined a higher penetration than the boron in relation to the copper in the wood pieces put through to the sap substitution treatment.

\subsection{Copper and boron preserved area in treated wood}

Regarding the copper preserved area, the discs from 4 and 1 positions were the ones that presented the highest preserved area percentage, an interesting characteristic for the position that is in contact to the ground, since copper has fungicide characteristics. Positions 2 and 3 had inferior values, not differing significantly among them.

In the boron preserved area, the 4 and 1 were also equal, presenting samples with higher treated area percentage. Again, the 2 and 3 positions disks did not present significant differences among their preserved areas. This is an interesting situation since the boron has an insecticide action and higher scents of the preferential attack region of many insects can make the preserving process more efficient.

The 4\% solution made preserved areas significantly superior than the 2 and $3 \%$ solutions that did not differ among themselves, when analyzed both by the copper as the boron. When comparing the areas preserved by copper and boron, it can be observed that copper provided more protection in all analyzed positions and testes concentrations.

The existence of association between the two groups (traditional methodology and penetration analysis proposal) was observed by the Pearson correlation with high values of correlation, both for boron $(0,93)$ as for copper $(0,88)$ penetration analysis. The correlation analysis show that the proposed methodology can be used as a complementary tool or even substitute the traditional method of preserving product penetration analysis, since the penetration is an indicator for the wood preserving efficiency

Revista Árvore, Viçosa-MG, v.40, n.4, p.731-739, 2016 
and the proposed method provides agility in the results acquisition.

The norm for treating plump pieces of eucalyptus for rural constructions NBR 9480, (ABNT, 2009) indicates that for a good preservation efficiency the sapwood might be entirely preserved, that is to say a $100 \%$ preserved area, thus the photocolorimetrical segmentation methodology is precise for informing the area percentage that was treated, both for the home-made as the industrial methods.

\subsection{CCB retention on treated wood}

The 2,3 and $4 \%$ a.i. solution did not provided the fence posts the minimum retention required by the NBR 9480, ABNT (2009), which is $6,5 \mathrm{~kg}$ i.a. $\mathrm{m}^{-}$ ${ }^{3}$ of wood treated with hydrosoluble salts, making the use of the impregnated pieces in this case limited to situations where the decay risk is small, not being suitable for direct ground contact or rain exposition.

The low retention values are justified by the low penetration of the preserving product; since the penetration did not happened in the entire sapwood region, as established by the NBR 9480, ABNT (2009), it was expected that the retention values were lower than the established. Thus, it can be seen that in position 1 , both the $3 \%$ a.i. ( $49 \%$ of preserved area) as the $4 \%$ a.i. solutions ( $79 \%$ of preserved area) solutions provided retention values that meet the ruling.

This situation can indicate low efficiency of the applied method and that the use of the fence posts in field condition can be compromised, when it is intended to increase the work life of these pieces even after they are impregnated, since the retained toxic ingredients for the xylophage organisms is low in the 3 and 4 positions of the fence post. The basal region of the pieces can also be a target of attacks, since the samples from the blooming zone (position 2) presented insufficient penetration and retention values to provided protection, mainly when the $2 \%$ a.i. is used.

\section{CONCLUSION}

The CCB impregnation in the wood showed low efficiency. The pieces submitted to the sap substitution treatment usually got satisfactory penetration layers, although lower than recommended by the technical standards. Therefore, the retention values were insufficient, hindering the use of the fence post in situations where there is contact with the ground.

The proposed digital methodology proved to be a good alternative to establish the treated area of the wood and could be better explored to act as a complementary or even a substitute to the traditional method, providing agility and precision for obtaining results.

\section{REFERENCES}

ASSOCIAÇÃO BRASILEIRA DE NORMAS TÉCNICAS - ABNT. NBR 6232: penetração e retenção de preservativos em madeira tratada sob pressão. Rio de Janeiro: 2013. 16p.

ASSOCIAÇÃO BRASILEIRA DE NORMAS TÉCNICAS - ABNT. NBR 9480: peças roliças preservadas de eucalipto para construções rurais - requisitos. Rio de Janeiro: 2009. 12p.

FARIAS SOBRINHO, D.W. Viabilidade técnica e econômica do tratamento preservativo da madeira de algaroba (Prosopis juliflora (Sw) D.C.), pelo método de substituição da seiva. 2003. 52f. Dissertação (Mestrado em Engenharia Agrícola) - Universidade Federal de Campina Grande, Campina Grande, 2003.

FARIAS SOBRINHO, D.W.; PAES, J.B.; FURTADO, D.A. Tratamento preservativo da madeira de algaroba (Prosopis juliflora (Sw) DC), pelo método de substituição de seiva. Cerne, v.11, n.3, p.225-236, 2005.

HUNT, G.M.; GARRATT, G.A. Wood preservation. $3^{\mathrm{a}}$.ed. New York: McGraw - Hill, 1967.433p.

LEPAGE, E.S. Preservativos e sistemas preservativos. In: LEPAGE, E.S. (Coord.). Manual de preservação de madeiras. São Paulo: IPT, 1986. v.1. p.279-314.

MODES, K.S.; BELTRAME, R.; VIVIAN, A.L.; SANTINI, E.J.; HESELEIN, C.R.; SOUZA, J.T. Combinação de dois métodos não industriais no tratamento preservativo de mourões de Eucalyptus grandis. Ciência Florestal, v.21, n.3, p.579-589, 2011. 
MORESCHI, J.C. Ensaios biológicos: uma nova alternativa para a determinação dos ingredientes ativos do preservativo CCA e estudos de interações. 1985. 128f. Tese (Professor Titular) - Universidade Federal do Paraná, Curitiba, 1985.

PAES, J.B. Viabilidade do tratamento preservativo de moirões de bracatinga (Mimosa scabrella Benth.) por meio de métodos simples, e comparações de sua tratabilidade com a do Eucalyptus viminalis Lab. 1991. 140f. Dissertação (Mestrado em Engenharia Florestal) - Universidade Federal do Paraná, Curitiba, 1991.

PAES, J.B.; GUEDES, R.S.; LIMA, C.R.; CUNHA, M.C.L. Tratamento preservativo de peças roliças de leucena (Leucaena leucocephala (Lam.) De Wit.) pelo método de substituição da seiva. Revista de Ciências Agrárias, v.47, p.231-246, 2007.

PAES, J.B.; MORESCHI, J.C.; LELLES, J.G. Avaliação do tratamento preservativo de moirões de Eucalyptus viminalis Lab. e de bracatinga (Mimosa scabrella Benth.) pelo método de substituição da seiva. Ciência Florestal, v. 15, n.1, p.75-86, 2005.

PAES, J.B.; RAMOS, I.E.C.; NASCIMENTO,
J.W.B. Eficiência do CCB na resistência da madeira de algaroba (Prosopis juliflora (Sw.) D.C.) a cupins xilófagos, em ensaio de alimentação forçada. Floresta e Ambiente, v. 15, n. 1, p. $1-12,2008$.

PAES, J.B.; LOPES, D.J.V.; GONÇALVES, F.G.; BRITO, F.M.S.; LOMBARDI, L.R. Efeito da concentração na ascensão de soluções preservativas preparadas com CCB em moirões de Eucalyptus. Floresta e Ambiente, v.21, n.3, p.384-393, 2014.

RAMOS, I.E.C.; PAES, J.B.; FARIAS

SOBRINHO, D.W.; SANTOS, G.J.C. Eficiência do CCB na resistência da madeira de algaroba (Prosopis juliflora (Sw.) D.C.) em ensaio de apodrecimento acelerado. Revista Árvore, v.30, n.5, p.811-820, 2006.

THORNTON, J.D.; JOHNSON, G.C.; NGUYEN, N.K. Revised CSIRO natural durability classification: in ground durability ratings for mature outer heartwood. Clayton: CSIRO Forestry \& Forest Products, 1997.

TORRES, P.M.A.; PAES, J.B.; LIRA FILHO, J.A.; NASCIMENTO, J.W.B. Tratamento preservativo da madeira juvenil de Eucalyptus camaldulensis Dehnh. pelo método de substituição de seiva. Cerne, v.17, n.2, p.275-282, 2011. 